IMPROVING PEDAGOGIC COMPETENCE OF NON-EDUCATION

TEACHERS IN PREPARING LESSON PLAN THROUGH

SUPERVISION ACADEMIC OF THE HEADMASTER

\author{
DELI RAHYUNI
}

Volume 1 Nomor 1

JIPS ISSN: 2579-5449

\begin{abstract}
Educational reform is not enough with changes in the curriculum sector, both the structure and the writing procedure. Updating the curriculum will be more meaningful if followed by changes in learning practices inside and outside the classroom. The success of curriculum implementation is strongly influenced by the ability of teachers to apply and actualize the

curriculum. Not infrequently the failure of curriculum implementation is caused by the lack of knowledge, skills and ability of teachers in understanding the tasks that must be implemented. This means that the teacher as the executor of the learning activities becomes the key to the implementation of the curriculum in the school.
\end{abstract}

Keywords: pedagogic competency,academic supervision

\title{
PENINGKATAN KOMPETENSI PEDAGOGIK GURU NON KEPENDIDIKAN DALAM PENYUSUNAN PERENCANAAN PEMBELAJARAN MELALUI SUPERVISI AKADEMIK KEPALA SEKOLAH
}

\begin{abstract}
ABSTRAK
Reformasi pendidikan tidak cukup hanya dengan perubahan dalam sektor kurikulum, baik struktur maupun prosedur penulisannya. Pembaharuan kurikulum akan lebih bermakna bila diikuti oleh perubahan praktik pembelajaran di dalam maupun di luar kelas. Keberhasilan implementasi kurikulum sangat dipengaruhi oleh kemampuan guru yang akan menerapkan dan

jarang kegagalan implementasi kurikulum disebabkan oleh kurangnya pengetahuan, keterampilan dan kemampuan guru dalam memahami tugas tugas yang harus dilaksanakannya. Hal itu berarti bahwa guru sebagai pelaksana kegiatan pembelajaran menjadi kunci atas keterlaksanaan kurikulum di sekolah.
\end{abstract} mengaktualisasikan kurikulum tersebut. Tidak

Kata kunci: kompetensi pedagogik, supervisi akademik 


\section{PENDAHULUAN}

Latar belakang, Upaya memperbaiki dan meningkatkan mutu pendidikan seakan tidak pernah berhenti. Banyak agenda reformasi yang telah, sedang, dan akan dilaksanakan. Reformasi pendidikan adalah restrukturisasi pendidikan, yakni memperbaiki pola hubungan sekolah dengan lingkungannya dan dengan pemerintah, pola pengembangan perencanaan, serta pola pengembangan manajerialnya, pemberdayaan guru dan restrukturisasi model model pembelajaran.

Reformasi pendidikan tidak cukup hanya dengan perubahan dalam sektor kurikulum, baik struktur maupun prosedur penulisannya. Pembaharuan kurikulum akan lebih bermakna bila diikuti oleh perubahan praktik pembelajaran di dalam maupun di luar kelas. Keberhasilan implementasi kurikulum sangat dipengaruhi oleh kemampuan guru yang akan menerapkan dan mengaktualisasikan kurikulum tersebut. Tidak jarang kegagalan implementasi kurikulum disebabkan oleh kurangnya pengetahuan, keterampilan dan kemampuan guru dalam memahami tugas tugas yang harus dilaksanakannya. Hal itu berarti bahwa guru sebagai pelaksana kegiatan pembelajaran menjadi kunci atas keterlaksanaan kurikulum di sekolah.

Dalam kurikulum 2004, guru diberi kebebasan untuk mengubah, memodifikasi, bahkan membuat sendiri silabus yang sesuai dengan kondisi sekolah dan daerahnya, dan menjabarkannya menjadi persiapan mengajar yang siap dijadikan pedoman pembentukan kompetensi peserta didik.

Upaya perwujudan pengembangan silabus menjadi perencanaan pembelajaran yang implementatif memerlukan kemampuan yang komprehensif.Kemampuan itulah yang dapat mengantarkan guru menjadi tenaga yang professional. Guru yang professional harus memiliki 5 (lima) kompetensi yang salah satunya adalah kompetensi penyusunan rencana pembelajaran. Namun dalam kenyataannya masih banyak guru yang belum mampu menyusun rencana pembelajaran sehingga hal ini secara otomatis berimbas pada kualitas out put yang dihasilkan dalam proses pembelajaran.
Perumusan dan pemecahan masalah Ada beberapa faktor yang menyebabkan guru kesulitan dalam menyusun rencana pembelajaran, diantaranya : (1) Guru tidak memiliki dasar pendidikan keguruan sehingga tidak dibekali dengan pengetahuan tentang perencanaan dan pelaksanaan pembelajaran. (2) Guru belum pernah mengikuti pelatihan penyusunan RPP sehingga mereka hanya copy paste pada temannya, padahal seringkali RPP hasil copy paste tidak relevan dengan situasi dan kondisi di sekolahnya sehingga RPP yang ada tidak bisa dijadikan acuan dalam proses pembelajaran. (3) Guru sudah pernah mengikuti pelatihan, tapi belum mampu menerapkannya di sekolah.

Kondisi tersebut tentu tidak bisa dibiarkan terus menerus, tetapi harus ada solusi dan tindakan nyata dari kepala sekolah sebagai penanggungjawab keberhasilan pendidikan di sekolahnya. Para guru tersebut harus mendapatkan pembinaan agar mampu meningkatkan kemampuannya dalam menyusun rencana pembelajaran, terutama bagi guru-guru yang memang tidak memiliki latar belakang pendidikan keguruan, sebelum mereka menempuh pendidikan tambahan agar memiliki akta IV sebagai bukti kewenangan mengajar.Kepala sekolah perlu melakukan suatu tindakan melalui supervisi akademik untuk membantu meningkatkan kemampuan mereka dalam menyelesaikan permasalahan yang dihadapinya.

Sehubungan dengan hal tersebut, maka masalah penelitian penulis rumuskan dalam bentuk pertanyaan penelitian sebagai berikut:“ Apakah kompetensi Pedagogik guru yang tidak memiliki latar belakang pendidikan keguruan dalam penyusunan rencana pembelajaran dapat ditingkatkan melalui supervisi akademik ?"

Cara pemecahan masalah, Upaya peningkatan kemampuan guru- guru yang tidak memiliki latar belakang pendidikan keguruan dalam menyusun rencana pembelajaran dapat dilakukan dengan berbagai cara diantaranya melalui pelatihan, seminar, workshop, menyediakan berbagai panduan dan modul. Namun setelah mempertimbangkan berbagai kelebihan dan kekurangannya, maka pembinaan 
yang terencana dan berkesinambungan dalam supervisi akademik melalui tehnik supervisi kelompok dianggap lebih efektif karena setiap permasalahan yang ditemukan bisa langsung dicarikan solusi bersama dan waktunya bisa disesuaikan dengan kemampuan masing masing guru. Dalam pelaksanaannya kepala sekolah akan dibantu oleh beberapa guru/ wakasek yang dianggap telah memiliki pengetahuan yang cukup dan kemampuan yang baik dalam menyusun rencana pembelajaran.

\section{METODE PENELITIAN}

Penelitian tindakan, Penelitian ini dilakukan dalam tiga tahapan, yaitu persiapan, pelaksanaan dan evaluasi dan refleksi, dan dilakukan minimal dalam dua siklus.

Pada tahap persiapan dibuat dibuat skenario kegiatan, jadwal waktu, tempat serta sarana pendukung lainnya seperti lembar observasi, serta angket. Penelitian dilakukan di SDN 15 Koto Kabun Kec.Ranah Pesisirsejak bulan Januari sampai bulan Februari 2017
Tujuan pnelitian, Sesuai dengan permasalahan diatas, maka tujuan utama dari penelitian tindakan sekolah ini adalah untuk membantu meningkatkan kompetensi paedagogik guru guru di SDN 15 Koto Kabun Kec.Ranah Pesisir, yang tidak memiliki latar belakang pendidikan keguruan, dalam menyusun rencana pembelajaran yang sesuai dengan standar kompetensi masing- masing pelajaran agar dapat menjadi acuan dalam proses pembelajaran sehingga peserta didik mampu mencapai kriteria ketuntasan minimal.

Subjek Penelitian, Penelitian ini ditujukan kepada guru guru semua mata pelajaran yang tidak memiliki latar belakang pendidikan keguruan yang berjumlah 5 orang yaitu : 1 orang guru mata pelajaran IPS, TIK, IPA, PKn,dan Penjas

Tindakan, Langkah-langkah PTS yaitu: perencanaan, pelaksanaan, pengamatan, dan refleksi. Langkah-langkah PTS seperti Gambar 1 berikut:

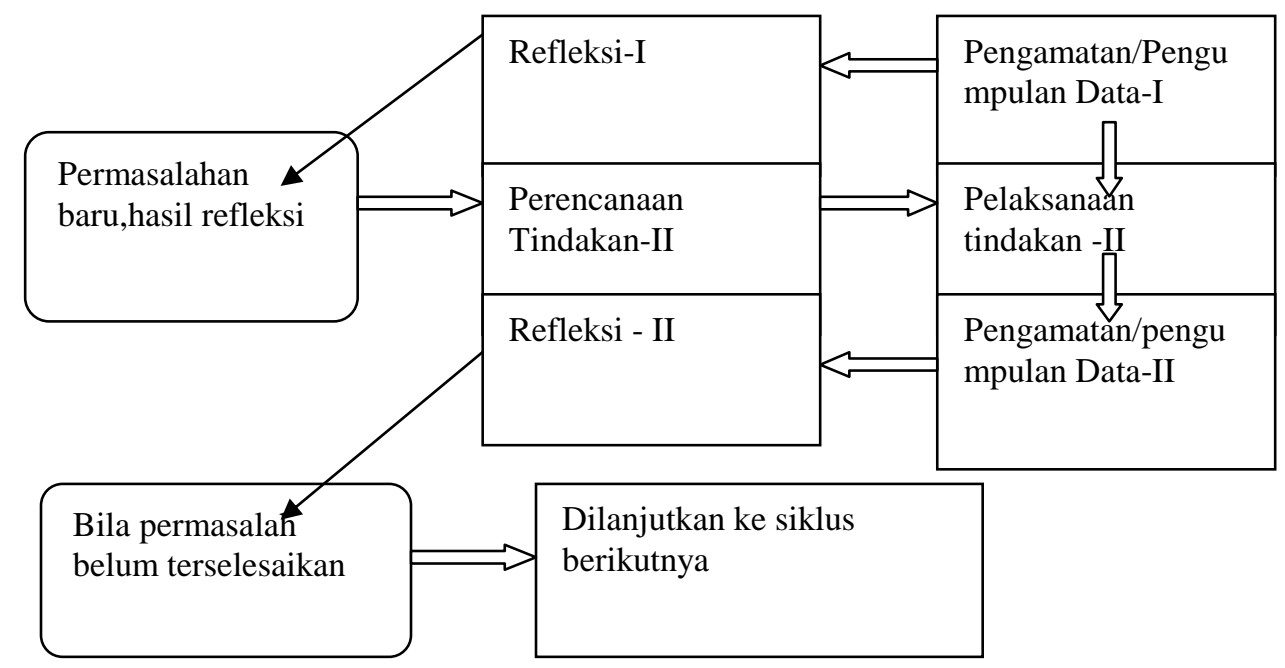

\section{Gambar 1. Langkah-langkah PTS}

Siklus 1, Perencanaan, Penelitian tindakan ini melibatkan 5 orang guru mata pelajaran yang tidak memiliki latar belakang pendidikan keguruan,yang ada di sekolah ini. Hal ini perlu dilakukan karena mereka tidak pernah dibekali dengan pengetahuan tentang pengelolaan pembelajaran sehingga mengalami kesulitan dalam menyusun perencanaan pembelajaran yang akan dilakukan di kelas sesuai dengan mata pelajaran masingmasing.Kegiatan ini dilakukan selama 2 bulan yaitu sejak bulan Januari sampai Februari 2017,dan dilakukan di sekolah dengan pengaturan waktu yang lebih fleksibel sehingga tidak mengganggu jadwal kegiatan pembelajaran. Sarana yang digunakan dalam 
kegiatan ini adalah silabus yang telah disusun bersama oleh setiap kelompok guru mata pelajaran dan Rencana Pelaksanaan Pembelajaran (RPP) yang disusun sendiri oleh guru yang bersangkutan sesuai dengan Standar kompetensi dan Kompetensi dasar pada masingmasing mata pelajaran. RPP inilah yang menjadi bahan acuan untuk menentukan materi pembinaan terhadap masing-masing guru, dan sekaligus menjadi alat ukur keberhasilan penelitian.

Kegiatan ini dilakukan dalam dua siklus hingga guru dinilai memiliki kemampuan untuk menyusun perencanaan pembelajaran yang baik. Dalam setiap siklus supervisor melakukan observasi dan penilaian terhadap perkembangan kemampuan setiap guru. Penelitian diawali dengan cara menyerahkan rencana pembelajaran yang disusun sendiri sesuai dengan mata pelajaran dan standar kompetensi masing masing kepada supervisor. Berdasarkan data tersebut supervisor melakukan pembinaan kepada guru sesuai dengan kesulitan masing masing guru.

Dalam menyusun RPP guru harus mencantumkan Standar Kompetensi yang memayungi Kompetensi Dasar yang akan disusun dalam RPP-nya. Di dalam RPP secara rinci harus dimuat Tujuan Pembelajaran,Materi Pembelajaran, Metode Pembelajaran, Langkahlangkah Kegiatan pembelajaran, Sumber Belajar, dan Penilaian

Guru menyusun RPP dengan mengikuti langkah-langkah Penyusunan Rencana Pelaksanaan Pembelajaran (RPP). Mencantumkan identitas, Nama sekolah, Mata Pelajaran, Kelas/Semester, Standar Kompetensi, Kompetensi Dasar, Indikator, Alokasi Waktu.

Alokasi waktu diperhitungkan untuk pencapaian satu kompetensi dasar yang bersangkutan, yang dinyatakan dalam jam pelajaran dan banyaknya pertemuan. Oleh karena itu, waktu untuk mencapai suatu kompetensi dasar dapat diperhitungkan dalam satu atau beberapa kali pertemuan bergantung pada karakteristik kompetensi dasarnya.

Mencantumkan Tujuan Pembelajaran, Tujuan Pembelajaran berisi penguasaan kompetensi yang operasional yang ditargetkan/dicapai dalam rencana pelaksanaan pembelajaran. Tujuan pembelajaran dirumuskan dalam bentuk pernyataan yang operasional dari kompetensi dasar. Apabila rumusan kompetensi dasar sudah operasional, rumusan tersebutlah yang dijadikan dasar dalam merumuskan tujuan pembelajaran. Tujuan pembelajaran dapat terdiri atas sebuah tujuan atau beberapa tujuan.

Mencantumkan Materi Pembelajaran, Materi pembelajaran adalah materi yang digunakan untuk mencapai tujuan pembelajaran. Materi pembelajaran dikembangkan dengan mengacu pada materi pokok yang ada dalam silabus.

Mencantumkan Metode Pembelajaran, Metode dapat diartikan benar-benar sebagai metode, tetapi dapat pula diartikan sebagai model atau pendekatan pembelajaran, bergantung pada karakteristik pendekatan dan/atau strategi yang dipilih.

Mencantumkan

Langkah-langkah

Kegiatan Pembelajaran, Untuk mencapai suatu kompetensi dasar harus dicantumkan langkahlangkah kegiatan setiap pertemuan. Pada dasarnya, langkah-langkah kegiatan memuat unsur kegiatan pendahuluan/pembuka, kegiatan inti, dan kegiatan penutup. Akan tetapi, dimungkinkan dalam seluruh rangkaian kegiatan, sesuai dengan karakteristik model yang dipilih, menggunakan urutan sintaks sesuai dengan modelnya. Oleh karena itu, kegiatan pendahuluan/pembuka, kegiatan inti, dan kegiatan penutup tidak harus ada dalam setiap pertemuan.

Mencantumkan Sumber Belajar, Pemilihan sumber belajar mengacu pada perumusan yang ada dalam silabus yang dikembangkan oleh satuan pendidikan. Sumber belajar mencakup sumber rujukan, lingkungan, media, narasumber, alat, dan bahan. Sumber belajar dituliskan secara lebih operasional. Misalnya, sumber belajar dalam silabus dituliskan buku referens, dalam RPP harus dicantumkan judul buku teks tersebut, pengarang, dan halaman yang diacu.

Penilaian dijabarkan atas teknik penilaian, bentuk instrumen, dan instrumen yang dipakai untuk mengumpulkan data. Dalam sajiannya dapat ituangkan dalam bentuk matrik horisontal atau vertikal. Apabila penilaian menggunakan teknik tes tertulis uraian, tes unjuk kerja, dan tugas rumah yang berupa proyek harus disertai rubrik penilaian. Format yang digunakan dalam penyusunan Rencana 
Pelaksanaan Pembelajaran (RPP) seperti terlihat di bawah ini. Kriterai Penilaian: Nilai 4 jika semua deskriptor tampak. Nilai 3 jika hanya 3 deskriptor yang tampak. Nilai 2 jika hanya 2 deskriptor yang tampak. Nilai 1 jika hanya 1 deskriptor yang tampak. Nilai 0 jika tidak ada deskriptor yang tampak

\section{HASIL DAN PEMBAHASAN}

Penelitian tindakan yang dilakukan diSDN 15 Koto Kabun Kec.Ranah Pesisirini dilakukan oleh kepala sekolah melalui tehnik supervisi akademik secara berkelompok sebagai upaya untuk meningkatkan kemampuan/kompetensi pedagogik guru dalam menyusun perencanaan pembelajaran di kelas. Penelitian dilakukan terhadap 5 orang guru yang tidak memiliki latar belakang pendidikan keguruan sehingga dianggap kurang kompeten dalam mengelola perencanaan dan pelaksanaan pembelajaran. Namun demikian permasalahan dalam penelitian tindakan ini difokuskan pada peningkatan kompetensi penyusunan Rencana Pelaksanaan Pembelajaran (RPP) dengan asumsi apabila guru sudah mampu menyusun RPP dengan baik, maka setidaknya dia sudah memiliki pedoman untuk melakukan langkahlangkah kegiatan pembelajaran di kelas sesuai dengan mata pelajaran masing-masing.

Kegiatan yang dilakukan dalam 2 siklus ini, dilakukan sejak bulan Januari sampai Februari 2017 dengan menitikberatkan pada unsur-unsur dan langkah-langkah penyusunan RPP sebagaimana yang terlihat pada kegiatan tindakan penelitian yang telah diuraikan pada BAB III.

Dari dari awal yang diperoleh pada kegiatan penelitian, terlihat bahwa $60 \%$ guru masih memiliki kesulitan dalam merumuskan indikator tujuan pembelajaran yang efektif sesuai dengan Standar Kompetensi dan Kompetensi Dasar masing-masing mata pelajaran. Selain itu guru juga masih menemukan kesulitan dalam memilih Strategi dan metode pembelajaran, serta menentukan teknik dan metode penilaian yang bisa mengukur pencapaian tujuan pembelajaran.Sementara untuk penentuan bahan belajar/ materi pembelajaran sudah dikuasai hingga $65 \%$ dan media yang direncanakan sudah $60 \%$ sesuai.Namun dalam penentuan kegiatan
Teknik analisis data dilakukan terhadap hasil RPP guru sebagai data awal kemampuan guru dan hasil observasi yang dilakukan selama proses pembinaan akan dianalisis secara deskriptif untuk mengukur keberhasilan proses pembinaan sesuai dengan tujuan penelitian tindakan sekolah ini.

pembelajaran belum terinci langkah-langkah dan alokasi waktu yang dibutuhkan.

Berdasarkan data hasil tindakan pada siklus 1 dengan titik berat pada kesulitankesulitan yang dihadapi, dengan cara memberikan penjelasan contoh-contoh yang relevan. Pada akhir kegiatan siklus 1 diperoleh peningkatan kemampuan guru sebagai berikut: Pada perumusan indikator tujuan pembelajaran sudah ada peningkatan hingga mencapai $60 \%$, Penentuan Bahan/materi pelajaran tetap pada 70\%,Kemampuan menentukan Strategi/metode Pembelajaran yang relevan meningkat menjadi $60 \%$, Perencanaan penggunaan media pembelajaran pada level $60 \%$ tetapi ada peningkatan pada variasi media yang digunakan, dan dalam penentuan rencana evaluasi pembelajaran juga mengalami peningkatan hingga $60 \%$.

Melihat hasil yang diperoleh pada refleksi kegiatan siklus 1, maka dilakukan tindakan penelitian pada siklus 2 dengan menggunakan hasil tindakan siklus 1 sebagai bahan masukan dalam perencanaan kegiatan siklus ini dengan tujuan untuk lebih meningkatkan dan menguatkan kemampuan guru dalam menyusun Rencana Pelaksanaan Pembelajaran(RPP) hingga bisa mencapai hasil minimal $70 \%$.

Pada akhir kegiatan siklus diperoleh hasil yang cukup menggembirakan yang memberikan indikasi tercapainya tujuan penelitian tindakan ini. Hasil yang diperoleh dapat kita lihat sebagai berikut: Perumusan tujuan pembelajaran hasil rata-rata menunjukkan angka $70 \%$. Pada penentuan bahan ajar diperoleh hasil $80 \%$,Penentuan strategi/metode pembelajaran ia dan alat mencapai $75 \%$ dengan variasi yang semakin beragam. Pada penentuan media dan alat pembelajaran ada peningkatan hingga $80 \%$, dan Perencanaan kegiatan evaluasi 
bisa mencapai $70 \%$ dan sudah mencantumkan, bentuk, jenis dan bahkan soal yang digunakan beserta kunci jawaban atau pedoman penilaiannya, serta mencantumkan alokasi waktu yang dibutuhkan. Sebelum dan selama proses penelitian tindakan, kita dapat melihat adanya peningkatan kemampuan guru pada masingmasing komponen perencanaan pembelajaran, sebagai berikut:

Pada komponen Perumusan indikator tujuan pembelajaran, terlihat peningkatan dari 40 $\%$ pada kemampuan awal, menjadi $60 \%$ pada siklus 1 dan meningkat menjadi $70 \%$ pada akhir kegiatan, Penentuan bahan dan materi pembelajaran, terdapat peningkatan kemampuan dari $65 \%$ menjadi $70 \%$ setelah siklus 1 dan lebih menguat menjadi $80 \%$ setelah siklus 2, Pemilihan Strategi dan metoda pembelajaran, yang didalamnya memuat langkah-langkah pembelajaran dan penentuan alokasi waktu yang digunakan,terlihat adanya peningkatan yang signifikan dari yang semula hanya $40 \%$ menjadi $60 \%$ pada siklus 1 dan meningkat lagi menjadi $75 \%$ setelah siklus 2. tidak terlihat adanya peningkatan yang cukup tajam, dalam komponen pemilihan Media dan alat pembelajaran juga

\section{SIMPULAN DAN SARAN}

Dari Proses Penelitian Tindakan sekolah yang di lakukan di SDN 15Koto Kabun yang berjudul Meningkatkan Kompetensi Pedagogik Guru non Akademik dalan Penyusunan Rencana Pelaksanaan Pembelajaran melalui Supervisi Akademik Kepala sekolah dapat disimpulkan bahwa : 1) Pada komponen Perumusan indikator tujuan pembelajaran, terlihat peningkatan dari 40 $\%$ pada kemampuan awal, menjadi $60 \%$ pada siklus 1 dan meningkat menjadi $70 \%$ pada akhir kegiatan. 2) Pada Komponen Penentuan bahan dan materi pembelajaran, terdapat peningkatan kemampuan dari $65 \%$ menjadi $70 \%$ setelah siklus 1 dan lebih menguat menjadi $80 \%$. 3) Dalam Komponen Pemilihan Strategi dan metoda pembelajaran, yang didalamnya memuat langkah-langkah pembelajaran dan penentuan alokasi waktu yang digunakan,terlihat adanya peningkatan yang signifikan dari yang semula hanya $40 \%$ menjadi $60 \%$ pada siklus 1 dan meningkat lagi menjadi $75 \%$ setelah siklus (1) Meskipun tidak terlihat adanya peningkatan yang terdapat adanya peningkatan dari $60 \%$ pada awal kegiatan dan setelah siklus 1, menjadi $80 \%$ setelah siklus 2. Peningkatan yang cukup signifikan juga dapat kita lihat pada komponen perencanaan evaluasi pembelajaran. Dari yang semula hanya $40 \%$ pada awal kegiatan, menjadi $60 \%$ pada akhir siklus 1 dan berhasil mencapai $70 \%$ pada akhir siklus 2 .

Melihat data perolehan hasil penelitian dalam kegiatan penelitian tindakan sekolah ini, dapat disimpulkan bahwa supervisi akademik yang dilakukan oleh kepala sekolah terhadap 5 orang guru yang tidak memiliki latar belakang pendidikan keguruan tersebut, berhasil meningkatkan kompetensi pedagogik mereka dalam menyusun Perencanaan Pembelajaran. Hal ini dimungkinkan karena adanya kerja sama yang baik antara kepala sekolah sebagai supervisor dengan para guru tersebut, yang didukung oleh adanya motivasi dan bimbingan dari kepala sekolah sehingga para guru memiliki antusiasme yang besar untuk dapat meningkatkan kemampuan mereka masing-masing dalam menyusun Rencana Pelaksanaan Pembelajaran (RPP) yang efektif.

cukup tajam, dalam komponen pemilihan Media dan alat pembelajaran juga terdapat adanya peningkatan dari $60 \%$ pada awal kegiatan dan setelah siklus 1, menjadi $80 \%$ setelah siklus 2 . (2) Peningkatan yang cukup signifikan juga dapat kita lihat pada komponen perencanaan evaluasi pembelajaran. Dari yang semula hanya $40 \%$ pada awal kegiatan, menjadi $60 \%$ pada akhir siklus 1 dan berhasil mencapai $70 \%$ pada akhir siklus 2. (3) Melihat data perolehan hasil penelitian dalam kegiatan penelitian tindakan sekolah ini, dapat disimpulkan bahwa supervisi akademik yang dilakukan oleh kepala sekolah terhadap 5 orang guru yang tidak memiliki latar belakang pendidikan keguruan tersebut, berhasil meningkatkan kompetensi pedagogik mereka dalam menyusun Perencanaan Pembelajaran.

SARAN, 1) Kegiatan supervisi akademik sangat baik dilakukan untuk membina guru meningkatkan kompetensinya. Sebaiknya kegiatan ini dilaksanakan secara terencana dan berkesinambungan. 2) Sebaiknya pembinaan ini 
dilanjutkan dengan supervisi akademik dalam pelaksanaan pembelajaran untuk mengukur kemampuan guru dalam mengimplementasikan rencana pembelajaran yang telah disusunnya. 3) Sebaiknya supervisi juga dilakukan terhadap semua guru secara bergilir dan menyangkut seluruh aspek kemampuan/ kompetensi guru seperti yang disyaratkan dalam permendiknas no 16 tahun 2007.

\section{DAFTAR PUSTAKA}

Departemen Pendidikan dan Kebudayaan RI. 1982. Alat Penilaian Kemampuan Guru: Buku I. Jakarta: Proyek Pengembangan Pendidikan Guru.

1982. Panduan Umum Alat Penilaian Kemampuan Guru.Jakarta: Proyek Pengembangan Pendidikan Guru.

. Alat Penilaian Kemampuan Guru: Hubungan antar Pribadi.Buku III. Jakarta: Proyek Pengembangan Pendidikan Guru.

. Alat Penilaian Kemampuan Guru:

Prosedur Mengajar. Buku II. Jakarta: Proyek Pengembangan Pendidikan Guru.

Suhardjono, A. Azis Hoesein, dkk (1995). Pedoman penyusunan KTI di Bidang Pendidikan dan Angka Kredit Pengembangan Profesi Guru. Digutentis, Jakarta : Diknas.

Suhardjono. 2005. Laporan Penelitian Eksperimen dan Penelitian Tindakan Kelas sebagai KTI, makalah pada
Pelatihan Peningkatan Mutu Guru di LPMP Makasar, Maret 2005.

Suhardjono. 2009. Tanya jawab tentang PTK dan PTS, naskah buku.

Suharsimi, Arikunto. 2002. Penelitian Tindakan Kelas, Makalah pada Pendidikan dan Pelatihan (TOT) Pengembangan Profesi bagi Jabatan Fungsionla Guru, 11-20 Juli 2002 di Balai penataran Guru (BPG) Semarang.

Suharsimi, Suhardjono dan Supardi. 2006. Penelitian Tindakan Kelas. Jakarta : PT Bumi Aksara.

Supardi. 2005. Penyusunan Usulan, dan Laporan Penelitian Penelitian Tindakan Kelas, Makalah disampaikan pada "Diklat Pengembangan Profesi Widyaiswara", Ditektorat Tenaga Pendidik dan Kependidikan Dirjen Pendidikan Dasar dan Menengah, Departemen Pendidikan Nasional. 